\title{
From student to professional: recent conservatoire graduates' experiences of instrumental teaching
}

This research, carried out across 2017-2018, investigated Royal Birmingham Conservatoire graduates' experiences of working as instrumental teachers. 31 participants (who graduated across 2012-16 and studied an optional 'Further Pedagogy' module in their final year) responded to a questionnaire, and two were observed whilst teaching, and subsequently interviewed (2018). Results indicate that $R B C$ students who chose to extend their pedagogical training beyond the core provision offered in the third year proved highly employable as instrumental teachers. Graduates considered teaching to be both fulfilling and challenging and were able to use insights gained 'on the job' to advise others. Whilst the sample was clearly limited, these findings contribute to an improved understanding of how instrumental teacher education in conservatoires might be further developed to effectively prepare students for the profession.

Keywords: conservatoire students; conservatoire graduates; conservatoire alumni; instrumental teaching; instrumental teacher education

\section{Introduction and research context}

The need to continue to build a workforce of skilled music education professionals is becoming ever more important in order to ensure longevity of music-making for future generations of young learners (Daubney et al, 2019; The Music Commission, 2019) and, according to the Review of Music Education in England (Henley, 2011:26), 'Conservatoires should be recognised as playing a greater part in the development of a performance-led music education workforce of the future'. Arguably, a 'music education workforce' should include well-qualified instrumental teachers who are trained to respond to the rewards and challenges of practices in instrumental teaching that are likely to be very different from their own early learning experiences in music. As conservatoires continue to develop their provision for training performers as instrumental teachers, their recent graduates are potentially an invaluable resource, providing experiences and insights from some of their earliest work in the field: 
Alumni are the link between conservatoires and the outside world. As practising professional musicians in their own right, they keep us alert to ongoing developments in the profession [...] Their feedback informs our curricula, ensuring that we are preparing students realistically for a rapidlychanging and increasingly competitive professional environment [...] Alumni provide professional opportunities, contacts, advice and guidance for students.

Sturrock (2007:9)

There is an established body of research pertaining to the experiences of emerging music educators in the USA, reviewed by Conway (2014:6) who recommended that 'continuing to document beginning teacher voice' highlights 'the need for new areas of inquiry within music education'. The challenges facing emerging instrumental teachers have also been explored in relation to the Australian system of music education (Watson, 2010). However, despite a call for more instrumental teaching research well over a decade ago (Triantafyllaki, 2005), research into the impact of pedagogical training on musicians who work as instrumental teachers in the UK is scarce, particularly in relation to those recently graduating from conservatoires.

The late Janet Mills claimed that 'the work of conservatoire students as instrumental teachers is under-researched' (2004a:145) and her significant body of work reflected her desire for 'raising the profile of training for instrumental teaching in higher education' (2006:388). Mills's studies include a focus on students' beliefs regarding what constitutes effective teaching based on their receipt of individual lessons at a conservatoire (2002); students' perceptions of the differences between instrumental teaching in schools and in Higher Education (Mills and Smith, 2003); students' attitudes and aspirations towards teaching as informed by current experience (2006); and an exploration of the extent to which instrumental teaching informs students' performance skills (Mills and Burt-Perkins, 2008). Mills found that conservatoire students expect and are keen to teach but felt they needed appropriate training. In a tribute, Cox (2008:6) wrote that 'Janet's sympathies lay with teachers' and that she 'wanted to empower them to do as effective a job as possible' through 'useful' research that stemmed 'from the unique perspectives and understanding of practitioners'. The 'Working in Music' project (2004b), initiated in 2001, explored 
such perspectives by investigating the careers of alumni from the Royal College of Music (RCM) revealing that those who initially took on teaching 'simply because they needed the money' (ibid:181) later found they could not be without it, either personally or musically. However, little insight was offered into the challenges they faced as early career teachers and it is unfortunate that, whilst participants were asked how well they thought their course had prepared them for their career and how it could be improved, the findings were not reported. Burt and Mills's (2006) study of conservatoire students 'taking the plunge' from school into Higher Education, undertaken as part of the longitudinal 'Learning to Perform' project instigated in 2004 (Mills et al, 2008) does, however, provide a useful model for exploring students' transition experiences from conservatoire study into employment. There are potential parallels to be drawn between the 'pivot points' (2006:67) experienced by the relatively inexperienced first-year undergraduate performers in the study and taking the first steps into the instrumental teaching profession.

Kite (1990) outlined the philosophy and practice of the Instrumental Teaching Course at the Guildhall School of Music at that time, where students were mentored by instrumental teachers from the ILEA (Inner London Education Authority) from 1987 until its demise in 1990, but it is not possible to ascertain the extent of the impact of the learning that took place, since the article did not seek to evaluate the outcomes of the training. Studies have since investigated how music students learn to teach in the absence of formal training (Haddon, 2009; Gonzalez, 2012) whilst others have explored the interrelated theoretical frameworks of professional identity, role/identity transition and transformative learning in relation to students becoming professional teachers (Schreib, 2007; Joseph and Heading, 2010; Reid and Bennett, 2014), though with the exception of Perkins $(2012 ; 2015)$ conservatoire students and graduates were not specifically considered. Elsewhere in the literature where conservatoire students have been the focus, teaching has often been overlooked, with the emphasis leaning towards the choices and challenges involved when attempting to forge a performance career (Burland, 2005; Creech et al, 2008; Gaunt et al, 2012), though the potential for learning how to teach through mentoring or participation in masterclasses and one-to-one lessons in the Higher Education context is implicit (Creech et al, 2009; Gaunt, 2010; 2011; Haddon, 2014). This is akin to the hidden learning opportunities uncovered by Haddon (2012) in her study of 
a university music department. Research undertaken by Perkins, Aufegger, and Williamon (2015) also offers useful insights into how students address the issue of learning 'on the job' when teaching older adults.

Examples of research that consider the place of instrumental teaching as part of graduating conservatoire students' portfolio careers include Miller and Baker (2007) who interviewed students at a conservatoire in the UK to ascertain their views on their pedagogical training and about teaching as part of a musical career; the 'Polifonia' project (AEC, 2010), summarised by Lennon and Reed (2012), where the changing landscape of instrumental teaching was discussed along with the competences needed by conservatoire graduates in order to carry out multiple roles in the music profession; and Bennett (2012) who collated a range of resources to support conservatoire graduates. Burt-Perkins (2008) embraced teaching as part of a diverse employment portfolio, and Latukefu and Ginsborg (2018) explored conservatoire students' perceptions and attitudes surrounding portfolio careers, with teaching in particular often being viewed as inferior to performance.

Nonetheless, there remains a paucity of industry-informed literature to support the development of instrumental teacher education for conservatoire students, as Norton, Ginsborg and Greasley (2019) concur. They view instrumental and vocal tuition as important, consider that little is known about musicians who participate in the profession, and that teachers' perspectives should be taken into account when developing qualifications. Their sample of 496 respondents included 96 conservatoire graduates who 'were more likely to teach young adults [...] and less likely to teach primary school pupils' (ibid:566) suggesting that their teaching experience and associated beliefs about vital knowledge, skills, and attributes may have been limited in scope.

An alternative starting point for developing new instrumental/vocal teaching qualifications could be to evaluate existing provision in conservatoires. At present, however, little is known about whether UK conservatoire graduates benefit from the pedagogical study and mentoring they undertake alongside their rigorous performance training, or of the extent to which this assists them in 'successfully navigating' (Weller, 2012:203) their early careers in a range of educational settings. 


\section{Conservatoire context and study aims}

Like other conservatoires, Royal Birmingham Conservatoire (RBC) offers a distinct Professional Development strand through its undergraduate and postgraduate courses to include both core and optional further training for prospective community musicians and instrumental teachers, with many modules including some form of professional placement work, in collaboration with external partners. From 2012, it has been possible for undergraduate BMus students at RBC to study an optional 'Further Pedagogy' module in the final, fourth year, in order to build on Principal Study-specific pedagogical training offered to all students at departmental level in year 3.

The Further Pedagogy module runs in partnership with Services for Education Music Service (SFE). SFE is lead organisation of the Birmingham Music Education Partnership, one of over 120 music hubs established in 2012, in response to the government's National Plan for Music Education (DfE, 2011), to provide access, opportunities and excellence in music education for all children and young people in England (Arts Council England, online). The professional placements that form part of the Further Pedagogy module enable RBC students to gain insight into the work of a music hub through observing, assisting and teaching various combinations of individual, small group and whole class instrumental lessons or ensemble rehearsals under the supervision of an assigned mentor, both in schools and as part of extracurricula activity. While SFE state 'This active engagement has had a very positive impact on the quality of students' job applications and interviews, and on their understanding of how to deliver effective teaching', there is a need to look beyond the anecdotal evidence in order to explore the longer-term impact of this training.

The current study aims to to discover the extent to which RBC graduates' final year pedagogical training prepared them for entering the instrumental teaching profession and to use the findings to inform future curriculum developments. Consequently, the following three, related research questions will be addressed:

1: To what extent did participants feel their pedagogical training prepared them for their early instrumental teaching careers? 
2: What challenges did participants typically encounter in the early stages of their instrumental/vocal teaching careers and which aspects of the job did they typically find the most rewarding?

3: What advice can graduates offer to aspiring instrumental teachers and what are the implications for conservatoire curricula?

For reasons that will be outlined below, a mixed-methods approach (Krathwohl, 1993; Mackenzie and Knipe, 2006; Creswell, 2012) was adopted, involving a combination of questionnaires, non-participant observations and semi-structured interviews.

\section{Research methods}

Research with former students invokes inevitable bias but an attempt was made to mitigate this by 'corroborating evidence from different individuals' for triangulation purposes (Creswell, 2012:259). Consequently, the research was 'regarded as a joint product of the participants, the researcher, and their relationship' (Finlay, 2002:531) and was conducted in two phases.

\section{Questionnaire}

Firstly, since the intention was to reach graduates across a wide geographical area and not just those employed locally, a semi-structured questionnaire format was chosen as a time-efficient and cost-effective method of gathering a mix of quantitative and qualitative data. The questionnaire was planned 'with data analysis in mind' whilst also considering the demands on the respondents' (Cohen, Manion and Morrison (2018:473-74). Participants would be required to complete 12 questions, designed to elicit a mix of quantitative and qualitative data, some multiple choice and others requiring a maximum of three free-text responses. The questionnaire was piloted by a current RBC student who offered feedback to iron out minor ambiguities and confirm that it would be possible to complete the questionnaire in approximately fifteen minutes. This was an important consideration since 'much of the research on respondent burden has focused on interview length and has generally found that longer surveys result in lower response rates' (Porter, Whitcomb and Weitzer, 2004:64). Questions aimed to elicit information regarding the 
range of professional activity participants had engaged in since leaving $\mathrm{RBC}$, the location of this activity and how long they had engaged in it. Where teaching was included amongst the activity reported, participants would be asked whether they felt the Further Pedagogy module had been useful to them in securing a position in relation to the identified activity and to give up to three reasons for their response; to indicate when they secured their first teaching position; what aspects of their teaching they most enjoyed and which they found most challenging. Participants would be required to rate their confidence and competence as teachers, to identify what aspects of their current skillset they had felt able to develop 'on the job' and those that the Further Pedagogy module could have better prepared them for.

Finally, participants would be given the opportunity to offer advice to current students based on their professional instrumental teaching experiences to date.

Since the module content and delivery did not change significantly across the period between 2012 (the module's first iteration) and 2016, and graduates' experiences of the module would have been largely similar, the pragmatic decision was made to contact all graduates from these four cohorts in order to gather a potentially large data set, whilst ensuring transparency and inclusivity in the selection process. Across the four-year period, cohorts had varied in size from 16-32 students, amounting to 94 students in total. Unfortunately, it was not possible to locate contact details for six graduates. Therefore, following the receipt of pilot study feedback and the necessary adjustments, the questionnaire was distributed by email to 88 graduates (using the Bcc facility to preserve anonymity) in December 2017.

\section{Observations and interviews}

Since the questionnaire targeted graduates with at least one year of professional experience, it was deemed necessary to also gather the perspectives of graduates at the very earliest stage of their instrumental teaching careers. For data source triangulation purposes (Coles and McGrath, 2010) the second phase of the research would therefore involve graduates who had commenced a teaching post with their placement host (SFE) just three months after leaving RBC in 2017 and who had taught for less than six months at the time of the study. While several recent leavers fulfilled the criteria, a significant number had enrolled onto one of RBC's postgraduate courses and were being taught by the researcher at the time of the 
study. Therefore, for ethical reasons, it was not appropriate to approach them, narrowing down the number of potential observation/interview participants to just two.

According to Robson (2016:321) observation can be used as part of 'an exploratory phase, typically in an unstructured form' to find out what is going on in a particular situation, thus, with consent from both aforementioned participants and their respective schools, a short observation (2.5 hours) of their teaching was arranged to provide context for a subsequent interview which took place within two hours of the observation itself. The interview schedule was designed according to recommendations by Cohen, Manion and Morrison (2018:506-526) wherein questions were designed to put the interviewee at ease, avoid prejudicial language, assumptions, leading or compound questions. The interviews lasted approximately 30 minutes and participants were encouraged to reflect in depth on the observed sessions, and how they compared to 'usual' sessions at that particular school and elsewhere. The observed sessions were also used as a starting point from which to explore graduates' experiences of teaching since they left RBC (akin to the work of Juuti and Littleton, 2012), and what they considered to be the most rewarding and challenging aspects of their role(s). Finally, participants were asked to discuss the relevance of the instrumental teacher education they received as students to their current work and to describe any support they received from their employer when starting out.

All aspects of the research (questionnaires, observations and semi-structured interviews) were conducted following a full ethical review process in consultation with the BERA Ethical Guidelines (2018, online). All prospective participants were issued with a participant information sheet and a consent form which explained that, should they agree to take part, their anonymity and confidentiality would be preserved when gathering, coding, analysing and storing data. It was made clear that one of the aims of the research was to further develop provision in instrumental teacher education for the benefit of current and future students, that graduates were under no obligation to participate and that if they declined the invitation to do so, they need not give a reason. Questionnaire responses were systematically filed on an encrypted hard drive device with each participant being allocated an alphanumeric code to enable 
the researcher to preserve participants' anonymity when reporting the findings. Since one of the desired outcomes of the research was to learn about specific graduates' destinations, and to build a network of alumni contacts from which current students could benefit, the questionnaire required participants to indicate their name, Principal Study specialism and year of graduation, with the assurance that this information would be used for administrative purposes only. For safeguarding purposes, a decision was taken not to record the observed sessions since children would be present - instead written notes would be taken. However, informed consent was obtained for the interviews to be recorded on a password protected device.

Of the 88 questionnaires distributed in December 2017, a total of 31 were returned a response rate of 35\%. Data were collated into an Excel spreadsheet and initially organised by participant. Statistical calculations were applied to quantitative data, whilst qualitative data was manually colour-coded to generate broad categories of ideas. The two interviews were transcribed and a similar coding process was undertaken during repeated readings (Creswell, 2012:243-251). The themes that emerged from this process were common to both the questionnaires and the interviews. Therefore, the nature of participants' instrumental teaching experiences, their attitudes towards instrumental teaching, including the challenges encountered and rewards enjoyed, and their views on the relevance of their undergraduate-level pedagogical training to the professional context will be discussed below with reference to both questionnaire participants (anonymised as P1-P31) and interviewees (anonymised as P32 and P33) as applicable.

\section{Research findings}

\section{Demographical information and teaching experience}

Of the 31 questionnaire respondents, 26 (84\%) reported that they had worked as an instrumental teacher, though one no longer worked in music. Of the remaining 25 instrumental teachers, the majority had stayed in the Midlands after graduating, but a geographical spread was achieved across the sample as shown in Figure 1:

Fig. 1 
All questionnaire respondents taught privately, the majority undertaking a combination of private and school-based work within music hubs and/or the independent sector. In one case, this included a post in a university music department and three participants worked in schools overseas (see Figure 2 below).

Fig. 2

Of seven participants who went on to study for a PGCE (Postgraduate Certificate in Education) or joined a SCITT (School Centred Initial Teacher Training) programme in the UK, four taught instrumental lessons privately alongside their classroom work. Of the two remaining participants not involved in any form of teaching, one went on to work as a full-time arts administrator within an educational setting and the other studied abroad after leaving RBC to focus on performance. 21 (84\%) of the practising instrumental teachers who participated in this study, earned part of their living from performance.

The 25 questionnaire participants who were working as instrumental teachers at the time of the study (in December, 2017) were asked when they secured their first instrumental teaching position and in addition, when they commenced private teaching. Figure 3 (below) shows that a significant proportion of graduates secured a teaching position in a school or other institution before they completed their studies, commencing their employment the following September, whilst Figure 4 indicates that the majority of respondents commenced private teaching whilst studying at RBC.

Fig. 3

Fig. 4

\section{Attitudes towards instrumental teaching}

The research revealed that, in general, students found the Further Pedagogy module helpful in raising their awareness of teaching as a potential career, and in some cases, it changed their professional outlook entirely: 
I went into the Conservatoire thinking I'm never gonna [sic] be a teacher. I'm gonna [sic] be a player like we all do, but obviously that's not how the music industry works, and actually, I really love teaching and I never thought I would, but I really enjoy it and it's something that I do want to be a part of my career (P32).

When asked whether the Further Pedagogy module had been useful to them in securing a position, 24 of the 25 current instrumental teachers (96\%) replied in the affirmative, claiming that the module proved to be 'an extra credential when applying for jobs' (P5) and that 'studying Further Pedagogy displayed [their] true interest in teaching to [their] employers' (P11).

The pedagogical knowledge and experience gained in relevant educational contexts whilst studying was also clearly valued by participants:

Shadowing gave me ideas for my own work and clarified what kind of organisations I wanted to work for. Also helpful was the opportunity to run an activity in class [...] to bounce ideas off fellow class members and see what worked/what didn't, how and why (P14).

The music service was specifically looking for people with experience of teaching whole classes. The shadowing I look part in and the material covered during classes gave me the experience and knowledge they were looking for. [The module] has helped me in interviews - when asked what experience I have or what I know about a certain aspect of teaching I have clear direct examples/literature to refer to (P29).

It would seem that attitudes towards teaching were most positive when participants felt confident in their own ability and where they were able to draw clear parallels with performance activity:

The module gave me confidence in my own ability as a teacher and performer enabling me to make the first steps into the profession [and] allowed me to form 
my own opinions and methods of teaching practice based in research, masterclasses, group activities and discussion (P8).

Participants were asked to rate their confidence and competence on a scale of 1-5 with 1 being not at all and 5 being completely. Figure 5 illustrates that 100\% of instrumental teachers participating in the study viewed themselves positively, selecting a rating of at least 3 for both confidence and competence, though it is revealing that, on average, graduates felt more competent than confident:

Fig. 5

This $100 \%$ statistic may be due to participants feeling competent in terms of being knowledgeable about their own instrumental/vocal specialism, but lacking confidence regarding unfamiliar and challenging aspects of early career teaching.

\section{Challenges}

Participants were given the opportunity to share the challenges they had encountered in the earliest stages of their teaching careers and to identify areas for which they would have appreciated more support during the module. Table 1 summarises the key points highlighted by questionnaire participants and shows the percentage of respondents making each point, in descending order. These data are then further illustrated by Figure 6:

Table 1

Fig. 6

Of the above, 'Administration' was the challenge most frequently alluded to by questionnaire respondents, which suggests that more time could be found within pedagogy curricula and teaching placements to discuss such aspects, though there was an acknowledgement from participants that the many different facets of administration can only be learned on the job. Of the remaining challenges listed, teaching strategies (in particular those relating to advanced pupils) and behaviour 
management came through strongly in the interviews and are therefore discussed further below.

Teaching strategies for advanced pupils

A 'need to develop a higher level (post grade 8) teaching skill set' (P15) was reported by three questionnaire participants. Another perspective, from the first of the two interviewees, suggests that this skill can partly be learned through experience. On the one hand, students need to develop knowledge of a wide repertoire in order to teach at advanced level as well as the ability to bring out the best in those who lack confidence:

I'm finding it so hard to teach them because they're learning repertoire that I've never played and I actually need to go away and practise it myself...I do struggle with a couple of my grade 8s who are a bit more timid (P32).

On the other, as suggested above, RBC students could be encouraged to take advantage of hidden learning opportunities (Haddon, 2012) by making stronger connections between their own instrumental training in Higher Education and the advanced level teaching they subsequently undertake. This could be particularly useful in helping new teachers to explain and articulate musical and technical concepts to their advanced pupils:

I find myself, especially to the higher-grade students, like my grade $6 \mathrm{~s}$ to $8 \mathrm{~s}$, [saying] all of the things that my teacher in my third and fourth year said to me. And I find myself using his phrases and terminology because he just explained it so well to me so why not let that explain it to someone else? There's definitely a huge overlap. Sometimes I have to play it myself and think 'oh what do I do?' before I can actually explain it to a pupil but I guess [...] every time you do it you just pick up another technique to explain things (P32).

As suggested by Gaunt et al (2012:41) mentoring by one-to-one teachers in conservatoires 'could provide a powerful environment to catalyse students' professional integration'. The findings from the current project suggest this could be 
specifically relevant in helping students to apply what they learn through performance to their own teaching, particularly at advanced level, as long as students are made aware that teaching as they were taught is unlikely to be wholly successful and alternative methods will need to evolve continually during one's teaching career.

\section{Behaviour management}

Of the 25 current practicing instrumental teachers in this study, $80 \%$ spent at least some of their time working in classrooms, teaching large groups. While on the one hand this is a striking statistic, it is unsurprising given the reach of Whole Class Ensemble Teaching (referred to by participants in this study as Whole Class Instrumental Teaching or WCIT). According to a 'Whole Class Ensemble Teaching Research Report' (Fautley, Kinsella and Whittaker, 2017:50) 77.3\% of Music Education Hubs and Music Services in England provide training for their staff in the delivery of WCET. However, it is not clear to what extent behaviour management techniques feature in such training, nor how much support is offered to new instrumental teachers and for how long.

The first interviewee perceived that behaviour management was one of the biggest challenges of their job:

The classroom management, away from the musical side of things, is a concept that I'm aware of but have no knowledge of really, and it's been a real struggle because a lot of the time we don't have any support from classroom teachers. Occasionally we'll have a TA [Teaching Assistant] with us but often they're just doing marking. They're not involved in the lesson, and that's been a real struggle for me. I just don't know where to begin with it because [...] I didn't learn how to control 30, you know, 8-year olds or whatever (P32).

The second observation and interview revealed the opinion that behaviour management could be learned on the job but with improved support from employers. 
For small groups, behaviour management was easier to learn. Whole class is where I've struggled. I think I've found my way but I would have appreciated a lot more help (P33).

Conversely the researcher observed both P32 and P33 employing competent behaviour management strategies during their teaching, but this is not to say that these new teachers felt confident in applying them.

Looking back at the first month or so I think I came across as the kind of teacher [the pupils] could walk on, even though I knew I had to step on things, I personally hate telling kids off. It's like what am I doing wrong? What could I do better to stop this from happening in the first place? (P33).

This strongly suggests that further steps need to be taken to better prepare conservatoire students for this challenging aspect of classroom-based group teaching that forms a large part of music hub work in particular.

\section{Rewards}

On a more positive note, graduates gained a tremendous amount of satisfaction from working as instrumental teachers and it is striking that when asked to indicate up to three aspects they find most rewarding, an overriding sense of personal fulfilment in their pupils' progress and achievements was revealed, as shown in Figure 7:

Fig. 7

Graduates reported that they enjoyed being able to share their knowledge and passion for music with the younger generation. 'Inspiring young people to enjoy and find room for music in their lives' (P8) was important to some, whilst others were keen to 'reach out to other individuals and help them learn new skills and build confidence (P10). Meanwhile, seeing children 'getting excited about their musicmaking' and 'cultivating friendships' (P19) as a result of it was particularly rewarding for others. 
At the same time, participants valued the professional development opportunities inherent in their teaching activity, recognising that 're-exploring the fundamentals of music' (P15) enabled useful connections to enhance their own performance activity. Similarly, Participant 18 appreciated

learning new things about my instrument(s) and becoming a better player by considering how I will teach a specific musical aspect in a creative and accessible way.

Meanwhile, being required to 'think about music in a different way' was mentioned by another graduate (P29) as a means of motivating and inspiring their pupils, and in turn this made them 'appreciate the benefits of music more'.

\section{Application of undergraduate pedagogical training to 'real life'}

Participants were asked to rate the Further Pedagogy module in terms of its relevance to their 'real life' instrumental teaching, particularly when first starting out, using a scale of $1-5$, with 1 being not at all and 5 being extremely. Despite the challenges of the instrumental teacher role discussed above, (for which the module has been providing greater support since 2018) participants responded positively as shown in Figure 8:

Fig. 8

This positive finding is reinforced by Participant 4 :

I was able to use ideas from when I observed at the music service, ideas that I use in my lessons today.

Graduates also seized the opportunity to offer advice to aspiring and new instrumental teachers as informed by their own personal experiences of 'learning on the job'. From these recommendations, the overarching themes 'adaptability and open-mindedness', 'employability' and 'professionalism' emerged. 
The need for adaptability and open-mindedness was reported by $68 \%$ of participants with the majority of recommendations relating to the need for conservatoire-trained musicians to adjust their thinking, to remember that each pupil is an individual and to differentiate their teaching accordingly, whilst not being afraid to try a range of methods:

Remember they are millennials [who] respond to apps or anything to do with technology. If possible bring that into your lessons ie. practice app, tuner app, metronome app (P4).

Consider that every pupil has different strengths, weaknesses, personalities, motivations, home life etc and adjust your approach accordingly (29).

Practical advice was also offered relating to demographical factors:

The school and area you're in makes so much difference to discipline and pupils' achievements, so as long you're doing your best for the pupils, it's sometimes not helpful to compare amount achieved to colleagues, for example (P17).

This advice is particularly useful in cases where students teach in settings which may differ from those in which they were taught as children, for example WCET. Indeed Participant 17's intention (above) was to reassure aspiring teachers and manage their expectations.

\section{Employability}

$76 \%$ of graduates strongly recommended that students/aspiring instrumental teachers make the most of the work placement opportunities offered to them both within and outside the module, in order to gather as wide a range of experience as possible before they graduate, and to help them stand out to employers. The importance of adopting a positive attitude was stressed, as was the need to develop enthusiasm for lifelong learning: 
Never stop learning and improving your teaching - read, watch, reflect, and apply (P31).

Another participant encouraged students to think broadly and to consider the links between classroom and instrumental teaching:

Get experience teaching as soon as possible. Don't wait until you leave college and hope to just "fall" into teaching. Get experience from a classroom music point of view too. It really helps to understand what is required in terms of GCSE and A-Level performances if you see it from the other side. It might help you work more collaboratively with the music teachers in your schools (P7).

However, it was made clear that while such activities were an excellent way to build a CV, they did not guarantee employment and that proactivity was paramount:

Have patience. It can take time to build up your career. You may need to seek another [non-musical] job first and arrange your teaching around it. It is a competitive industry and isn't likely to all happen straight away. Make your name known in any way possible [...] I have found that the best way to gain [teaching work] is through word of mouth (P23).

\section{Professionalism}

Professionalism appeared to be closely related to employability in that to gain and sustain teaching work, participants believed that teachers need to be both 'businessminded' and have 'good people skills'. Such facets were considered important by $92 \%$ of participants who warned of the need for good organisation, timemanagement skills and the fostering of effective relationships:

Regardless of how grumpy you actually are, be as positive a presence as you possibly can be to everybody (P19).

Forming a good relationship with members of staff at the school you are teaching at will not only create a good impression but will mean your pupils 
will view you as a member of their school rather than a visiting teacher where the school rules don't apply to them (they can be very intuitive). This includes immersing yourself in the school's values, behaviour management system and knowing what they are doing in their school curriculum (P29).

Finally, participants advised that aspiring instrumental teachers should expect to experience a period of adjustment as they make the transition from student to professional:

When you're in music college you're always surrounded by incredible musicians and you're always aspiring to be one of them, so it's a strange situation to be in [whether] you're teaching beginners [...] or grade 8 people. To them you're the one who's the amazing person at your instrument so that's a weird thing to get used to (P32).

\section{Conclusion}

The current study has considered the value of pedagogical training via a final-year undergraduate module in a UK conservatoire delivered, since 2012, in partnership with one of England's largest music hubs. The perspectives of 31 recent graduates were taken into account as a means of evaluating the module and its effectiveness in preparing students for early-career activity in the field of instrumental teaching. Findings from a questionnaire were triangulated with two interviews which were contextualised by observations of participants' teaching in schools. The results revealed that the majority of participants (96\%) felt their pedagogical training, to a great extent, prepared them well for their early instrumental teaching careers (Question 1) with participants reporting positive scores in relation to their own confidence and competence in teaching. Furthermore, it appears that RBC students who studied the Further Pedagogy module in their final undergraduate year became highly employable, with $52 \%$ securing a teaching position with a music service or school and 65\% commencing private teaching even before they graduated. Graduates reported that they found the work rewarding and fulfilling, particularly in relation to inspiring the next generation of learners and facilitating their growth and progression as people and as musicians. 
In contrast to the positive findings reported above, recent graduates evidently experienced numerous challenges in their early teaching careers (Question 2). These included dealing with multiple administrative tasks, motivating pupils, finding and articulating appropriate teaching strategies for advanced pupils, building trusting relationships with pupils' parents, managing behaviour (particularly in whole-class instrumental lessons), planning lessons, devising resources and differentiating activities for learners, coping in spite of limited support from school staff, working with technology and feeling lonely. Furthermore, advanced teaching and behaviour management were corroborated as significant challenges by the two interviewees. There are striking similarities to be drawn with the American studies mentioned above (Conway, 2014) in that classroom management and administrative aspects were amongst the significant challenges encountered by participants, even in light of the different educational systems involved. Intriguingly, 'behaviour' and 'paperwork' had also emerged as concerns in a study of conservatoire students' views about music teaching in schools (Mills, 2005:67-68).

Participants were able to offer industry-informed advice to aspiring instrumental teachers that has implications for curricula within RBC, as well as for the conservatoire sector as a whole (Question 3). Such advice included the need for conservatoire students to adjust their thinking about music in order to successfully engage others. The need to be adaptable and open-minded was considered important by $68 \%$ of participants who had learned through their early teaching experiences that teaching in the way they themselves had been taught simply did not prove successful in the majority of cases. Advice was also offered to enhance student's employability prospects, with $76 \%$ of participants recommending professional placement activity as crucial for developing skills relevant for future teaching work and 92\% emphasising the importance of professional conduct both in and outside the workplace. Indeed, the current study has generated a network of alumni contacts, with a wealth of insights acquired through their early professional experiences, who can offer inspiration to all music students.

The results of this study are encouraging, given that in conservatoires, there are 'dominant discourses placing performance as the pinnacle of success for a musician. 
[Therefore] it is not uncommon for students to feel "second-rate" if they redefine their career aims to include activities beyond performance' (Bennett, 2012:11).

An obvious way to build on the current findings would be to undertake a longitudinal study of recent graduates as they accumulate experience in a range of instrumental teaching contexts over time, in order to identify pivotal moments that influence their practice, akin to the 'pivot points' involved in the transition from school to conservatoire (Burt and Mills, 2006:67). A further valuable endeavour could be to build on the work of researchers such as Mills and Burt-Perkins (2008), Creech et al (2009); Gaunt (2010; 2011); and Haddon (2012; 2014) so as to examine the extent to which conservatoire students naturally make connections, by encouraging them to use their performance practice as a starting point from which to develop their instrumental teaching skills rather than the other way around. Furthermore, if (after Mills) such research is to be 'potentially useful' (Cox, 2008: 6), insights gained from the real-life experiences of current students and alumni would ideally inform future curriculum developments in conservatoires. The Association of European Conservatoires (2010:44-45) cited in Lennon and Reed (2012:289) support this notion, suggesting that conservatoires and other Higher Education Institutions can learn from their recent graduates' experiences in professional instrumental teaching contexts in order to continue developing their provision for instrumental teacher education and ensure that it is current and highly relevant. They state: 'Student learning (which starts in the conservatoire and continues throughout lifelong learning) and the learning outcomes of these institutions can be tested within the profession through the performance of their graduates.'

Clearly, this project has had its limitations. Even though the sample was spread across a fairly wide geographical area, involving participants who had gained experience of working in a variety of educational settings, the sample size was small and linked to a single, self-selecting module in one conservatoire. Furthermore, the evident advantages in relation to mutual trust and access were eclipsed by the obvious disadvantages pertaining to researcher bias. It is possible that a less positive picture would have emerged had the participant sample been taken from a compulsory module taken by a whole-year group, or had the participants been unknown to the researcher. Nevertheless, 'knowing that students seek to learn from 
their peers' (Perkins, 2012: 21), it is pertinent that the current research project has generated practical guidance informed by graduates' experiences in real-world teaching scenarios that can be used to influence current and future generations of students who are either aspiring to teach, or indeed are already embarking on their early instrumental teaching careers. Despite the positive attitudes communicated by $\mathrm{RBC}$ graduates in this study, there is clearly much more to be done in relation to preparing RBC students to teach their Principal Study specialism, particularly in whole-class instrumental settings and to advanced students, yet these findings have far wider implications. Given that 'the development of a diverse and skilled music education workforce' is proposed as one of eight 'outcomes for the 2020s' by The Music Commission (2019:7) and that the Music Education: State of the Nation report (Daubney et al, 2019:31) recommends 'that there is a sufficient number of properly qualified teachers coming through to support the delivery of music education in our schools and Hubs', the findings of the current study, particularly the 'advice' provided by RBC alumni, contribute to a greater understanding of exactly how instrumental teacher education in conservatoires and other Higher Education Institutions might be further developed to prepare students effectively for an evidently rewarding and worthwhile branch of the music profession.

Word count (excluding title, abstract and acknowledgements): 6812 
References

ARTS COUNCIL ENGLAND (online) Music Education Hubs. Retrieved from: https://www.artscouncil.org.uk/music-education/music-education-hubs

ASSOCIATION OF EUROPEAN CONSERVATOIRES: POLIFONIA WORKING GROUP FOR INSTRUMENTAL AND VOCAL MUSIC TEACHER EDUCATION (2010) Handbook - Instrumental and Vocal Teacher Education: European Perspectives. Brussels: AEC Publications.

BENNETT, D. (2012) Life in the Real World - How to Make Music Graduates More Employable. Illinois: Common Ground Publishing.

BERA (2018) Ethical Guidelines for Educational Research ( $4^{\text {th }}$ edn, online). British Educational Research Association. Retrieved from:

https://www.bera.ac.uk/publication/ethical-guidelines-for-educational-research-2018

BURLAND, K. (2005) Becoming a musician: a longitudinal study investigating the career transitions of undergraduate music students. PhD diss., University of Sheffield.

BURT, R. \& MILLS, J. (2006) Taking the plunge: The hopes and fears of students as they begin music college. British Journal of Music Education, 23 (1), 51-73.

BURT-PERKINS, R. (2008). Students at a UK conservatoire of music: Working towards a "diverse employment portfolio"? In D. Bennett \& M. Hannan (Eds), Inside, outside, downside up: Conservatoire training and musicians' work (pp. 49-60). Perth: Black Swan Press.

COHEN, L., MANION, L. \& MORRISON, K. (2018) Research Methods in Education (8 $8^{\text {th }}$ edn). London: Routledge.

COLES, A., \& MCGRATH, J. (2010) Your Education Research Project Handbook. Essex: Pearson. 
CONWAY, C.M. (2014) The experiences of first year music teachers: A literature review. Update: Applications of Research in Music Education, 33 (2), 65-72.

COX, G. (2008) A tribute. In C. Madsen, G. Cox, S. Tommey, A. Dobson, R. BurtPerkins \& R. Walker. A dedication to Janet Mills. British Journal of Music Education, 25 (1) 5-8.

CRESWELL, J.W. (2012) Educational Research: Planning, Conducting and Evaluating Quantitative and Qualitative Research ( $4^{\text {th }}$ edn). Boston: Pearson.

CREECH, A., PAPAGEORGI, I., DUFFY, C., MORTON, F., HADDON, E., POTTER, J., DE BEZENAC, C., WHYTON, T., HIMONIDES, E., \& WELCH, G. (2008) From Music Student to Professional - the process of transition. British Journal of Music Education, 25 (3), 315-331.

CREECH, A., GAUNT, H., HALLAM, S., \& ROBERTSON, L. (2009) Conservatoire students' perceptions of masterclasses. British Journal of Music Education, 26 (3), 315-331.

DAUBNEY, A., SPRUCE, G. \& ANNETTS, D. (2019) Music Education: State of the Nation. Report by the All-Party Parliamentary Group for Music Education, the Incorporated Society of Musicians and the University of Sussex.

DEPARTMENT FOR EDUCATION (2011) The Importance of Music: A National Plan for Music Education.

FAUTLEY, M., KINSELLA, V., \& WHITTAKER, A. (2017) Whole Class Ensemble Teaching Research Report. Faculty of Health, Education and Life Sciences, Birmingham City University (with funding from Music Mark; Arts Council of England).

FINLAY, L. (2002) 'Outing' the researcher: The provenance, process and practice of reflexivity. Qualitative Health Research, 12 (4), 531-545. 
GAUNT, H. (2010) One-to-one tuition in a conservatoire: the perceptions of instrumental and vocal students. Psychology of Music, 38 (2) 178-208.

GAUNT, H. (2011) Understanding the one-to-one relationship in instrumental/vocal tuition in Higher Education: Comparing student and teacher perceptions. British Journal of Music Education, 28 (2), 159-179.

GAUNT, H., CREECH, A., LONG, M. \& HALLAM, S. (2012) Supporting conservatoire students towards professional integration: one-to-one tuition and the potential of mentoring. Music Education Research, 14 (1), 25-43.

GONZALEZ, M.J.F. (2012) How students learn to teach? A case study of instrumental lessons given by Latvian undergraduate performer students without prior teacher training. Music Education Research, 14 (2), 227-242.

HADDON, E. (2009) Instrumental and vocal teaching: how do music students learn to teach? British Journal of Music Education, 26 (1), 57-70.

HADDON, E. (2012) Hidden learning and instrumental and vocal development in a university music department. PhD Diss., University of York.

HADDON, E. (2014) Observational learning in the music masterclass. British Journal of Music Education, 31 (1), 58-68.

HENLEY, D. (2011) Music Education in England - a review by Darren Henley for the Department for Education and the Department for Culture, Media and Sport. Department for Education.

JOSEPH, D. \& HEADING, M. (2010) Putting theory into practice: moving from student identity to teacher identity. Australian Journal of Teacher Education, 35 (3), 75-87. 
JUUTI, S., \& LITTLETON, K. (2012) Tracing the transition from study to a contemporary creative working life: the trajectories of professional musicians. Vocations and Learning, 5 (1), 5-21.

KITE, C (1990) Training music students for a career in instrumental teaching; a conservatoire's point of view. British Journal of Music Education, 7 (3), 263-267.

KRATHWOHL, D.R. (1993) Methods of educational and social science research: An integrated approach. New York: Longman.

LENNON, M. \& REED, G. (2012) Instrumental and vocal teacher education: competences, roles and curricula. Music Education Research, 14 (3), 285-308.

LATUKEFU, L. \& GINSBORG, J. (2018) Understanding what we mean by portfolio training in music. British Journal of Music Education, 36 (1), 87-102.

MACKENZIE, N., \& KNIPE, S. (2006) Research dilemmas: Paradigms, methods and methodology. Issues in Educational Research, 16 (2), 193-205.

MILLER, J., \& BAKER, D. (2007) Career orientation and pedagogical training: Conservatoire undergraduates' insights. British Journal of Music Education, 24 (1), 5-19.

MILLS, J. (2002) Conservatoire students' perceptions of the characteristics of effective instrumental and vocal tuition. Bulletin of the Council for Research in Music Education, 153/154, 78-82.

MILLS, J. \& SMITH, J. (2003) Teachers' beliefs about effective instrumental teaching in schools and higher education. British Journal of Music Education, 20 (1), 5-27.

MILLS, J. (2004a). Conservatoire Students as Instrumental Teachers. Bulletin of the Council for Research in Music Education, 161/162, 145-153.

MILLS, J. (2004b) Working in music: becoming a performer-teacher. Music Education Research, 6 (3), 245-261. 
MILLS, J. (2005) Addressing the concerns of conservatoire students about school music teaching. British Journal of Music Education, 22 (1), 63-75.

MILLS, J. (2006) Performing and teaching. The beliefs and experience of music students as instrumental teachers. Psychology of Music, 34 (3), 372-390.

MILLS, J. \& BURT-PERKINS, R. (2008) Early experience as an instrumental teacher: help or hindrance? In S. Malbrón \& G. Mota (Eds). Proceedings of the $22^{\text {nd }}$ International Seminar on Research in Music Education, Portugal, 13-18 July.

MILLS, J. et al (2008). Learning to Perform: Instrumentalists and Instrumental Teachers: Full Research Report ESRC End of Award Report, RES-139-25-0101. Swindon: ESRC.

NORTON, N., GINSBORG, J. \& GREASLEY, A. (2019). Instrumental and vocal teachers in the United Kingdom: demographic characteristics, educational pathways, and beliefs about qualification requirements. Music Education Research, 21 (5), 122.

PERKINS, R. (2012) Rethinking 'Career' for Music Students - Identity and Vision. In D. Bennett (Ed.), (2012) Life in the Real World - How to Make Music Graduates More Employable (pp. 11-26). Illinois: Common Ground Publishing.

PERKINS, R. AUFEGGER, L. \& WILLIAMON, A. (2015) Learning through teaching: exploring what conservatoire students learn from teaching older adults. International Journal of Music Education, 33 (1), 80-90.

PERKINS, R. (2015) Bourdieu Applied in the Analysis of Conservatoire Learning Cultures. In P. Burnard, Y. Hofvander Trulssohn and J. Söderman (Eds), Bourdieu and the Sociology of Music Education (pp.99-112). Surrey: Ashgate. 
PORTER, S. R., WHITCOMB, M. E. \& WEITZER, W. H. (2004) Multiple surveys of students and survey fatigue. New Directions for Institutional Research, Special Issue, 63-73.

REID, A., \& BENNETT, D. (2014) Becoming and being a musician: The role of creativity in students' learning and identity formation. In G. Caruthers (Ed.). Proceedings of the $20^{\text {th }}$ International Seminar of the ISME Commission on the education of the Professional Musician. July, Belo Horonte, Brazil.

ROBSON, C., \& MCCARTAN, K. (2016) Real World Research - a Resource for Users of Social Research Methods in Applied Settings ( $4^{\text {th }}$ edn). London: John Wiley \& Sons Ltd.

SCHREIB, J.W. (2007) Roles, identity, socialisation and conflict: the transition from music student to music teacher (a literature review). Society for Music Teacher Education Areas of Strategic Planning and Action.

STURROCK, S. (2007) Today's Student; Tomorrow's Alumnus: Cultivating Good Alumni Relationships in Conservatoires. AEC Publications.

THE MUSIC COMMISSION (2019) Retuning Our Ambition for Music Learning: Every Child Taking Music Further. ABRSM/Arts Council England.

TRIANTAFYLLAKI, A. (2005) A Call for More Instrumental Teaching Research. Music Education Research, 7 (3), 383-387.

WATSON, A. (2010) Musicians as instrumental teachers: Issues from an Australian perspective. International Journal of Music Education, 28 (2), 198-203.

WELLER, J. (2012) Transitioning to Professional Life. In D. Bennett (2012) Life in the Real World - How to Make Music Graduates More Employable (pp 203-204). Illinois: Common Ground Publishing. 


\section{Tables and Figure captions}

Table 1: Challenges for alumni starting out in the instrumental teaching profession

\begin{tabular}{|c|c|}
\hline $\begin{array}{l}\text { Administration - including timetabling, managing own time, recruiting pupils, } \\
\text { claiming payment, taking registers, writing reports, doing tax returns }\end{array}$ & $35 \%$ \\
\hline $\begin{array}{l}\text { Motivating pupils - including encouraging pupils to practise (scales in particular), } \\
\text { unlocking their musical tastes and preferences, maintaining enthusiasm where pupils } \\
\text { lack interest }\end{array}$ & $29 \%$ \\
\hline $\begin{array}{l}\text { Teaching strategies - including explaining technical, rhythmic or musical concepts in } \\
\text { accessible ways to beginners, teaching concepts which come naturally to you as a } \\
\text { performer to advanced pupils }\end{array}$ & $29 \%$ \\
\hline $\begin{array}{l}\text { Relations with parents - including managing their expectations in relation to graded } \\
\text { examinations, gaining their trust in your professional opinion, seeking their support } \\
\text { with their child's practice }\end{array}$ & $29 \%$ \\
\hline $\begin{array}{l}\text { Behaviour management - including when working in schools with poor discipline, } \\
\text { and working with large groups, especially WCIT where there is often a lack of class } \\
\text { teacher/TA support }\end{array}$ & $22 \%$ \\
\hline $\begin{array}{l}\text { Differentiation - including tracking progress, particularly in whole classes, and } \\
\text { working with SEND pupils }\end{array}$ & $19 \%$ \\
\hline Planning and resources - for WCIT, and structuring short 20 minute lessons & $19 \%$ \\
\hline $\begin{array}{l}\text { Lack of support from schools - including poor communication, poorly run } \\
\text { departments, little support in WCIT due to teachers spending the time on marking } \\
\text { and administration }\end{array}$ & $10 \%$ \\
\hline Technology - how to incorporate it into teaching & $3 \%$ \\
\hline Loneliness - particularly when working as a private teacher & $3 \%$ \\
\hline
\end{tabular}

Fig. 1: Geographical locations of instrumental teaching alumni sample

Fig. 2: Types of school/institutional teaching undertaken by alumni

Fig. 3: When participants secured their first instrumental teaching position

Fig. 4: When participants commenced private teaching

Fig. 5: Participant self-evaluation of confidence and competence as instrumental teachers

Fig. 6: Challenges for alumni starting out in the instrumental teaching profession

Fig. 7: Rewarding aspects of instrumental teaching 
Fig. 8: Alumni views about the relevance of the module to their early career teaching 